\title{
Comparison Study of Toxicity Kohl and Black Stone Hair Dye
}

\section{Ahmed Shihata*}

Forensic Medicine Authority - Chemical Lab, Egypt

\begin{abstract}
Background: Kohl has been known and used traditionally as eye cosmetic for women and babies. Kohl is a gray or black eye cosmetic used in middle east, India, Pakistan, and some parts of Africa. There are different forms of commercially available preparation: stone powder finger rods, or pencils. Black hair dye is widely used in Upper Egypt, traditionally know as "stone hair dye". Many cases of toxicity and mortality either due to accidental or deliberate ingestion of hair dyes were reported in Egypt and other countries.

Objective: To determination the elements in Kohl and Hair Dye from market and comparison these elements in liver and kidney of two women reported in Upper Egypt. Toxicity of Kohl due to Lead, Aluminum, Zinc, and some other metals. While black stone is a traditional hair dye popularly used in the third world as a deep black coloration substance and cheap. Unfortunately, many persons use it as a criminal tool for homicide or suicide. (P-Phenylenediamine PPD) may cause severe dermatitis, gastritis, renal failure, convulsions, and coma in humans. So that (PPD) and other nitro aromatic compounds the main toxic ingredient of hair dye so that it's very dangerous transdermal and the concentration of Lead, Aluminum, Zinc, and some other metals is lower than in Black hair dye. This research was studied that in two cases (human) has died.
\end{abstract}

Keywords: Kohl; Black stone hair dye; Metals; Toxicity; Plasma emission mass spectrometer

\section{Introduction}

For centuries, kohl (a mixture of soot or antimony with other ingredients) was the popular choice for decorating the eyes. No one can forget the Ancient Egyptians and their dramatic use of eye color and liner. These eye products often contained green malachite or galena (gray lead ore), cerussite (white carbonate of lead), oils or fats. Ancient Roman women used eyeliners made from items ranging from soot and antimony powder (a semi-metallic chemical element) to galena [1]. To brighten eyes, women of Elizabethan England used drops of belladonna (derived from nightshade, which is a poisonous plant).

Kohl is a gray or black eye cosmetic for women and babies in Middle East, India, Pakistan and some parts of Africa. Kohl is available today basically the same things that were familiar millennia ago as an ancient Egyptian eye makeup. It may be tempting to think that because Kohl has been used traditionally as an eye cosmetic in some parts of the world in must be save. There are different forms of commercially available preparation: stone powder finger rods, or pencils. Kohl that is available today is basically the same things that were familiar millennia ago as an ancient Egyptian eye makeup. However, woman has been reported first case 2006 as homicide in Upper Egypt. No $\mathrm{LD}_{50}$ values for inorganic lead. Irreversible severe brain damage (overt encephalopathic symptoms) occurs after exposure to high concentrations of lead. The onset of encephalopathic symptoms is very rapid; convulsions, coma, and death can occur within 48 hours in individuals appearing to be asymptomatic [2]. The fatal dose is estimated at $500 \mathrm{mg}$ of absorbed lead [3]. For a long time, Aluminum ( $\mathrm{Al}$ ) has been considered an indifferent element from a toxicological point of view. In recent years, however, $\mathrm{Al}$ has been implicated in the pathogenesis of several clinical disorders, such as dialysis dementia, the fulminant neurological disorder that can develop in patients on renal dialysis. The $\mathrm{LD}_{50}$ after injection of soluble cadmium compounds is in the range of $2.5-25 \mathrm{mg} / \mathrm{kg}[4,5]$. Shortly after injection, severe endothelial damage occurs in the small vessels of the peripheral nervous system and testes [5,6]. After some hours, marked liver changes are seen and liverdamage may be the cause of death after acute parenteral intoxication. $\mathrm{LD}_{50}$ of copper $(115 \mu \mathrm{M})$ was increased six times $(710 \mu \mathrm{M})$ in presence of zinc for PBMCs [7]. Poisoning following oral ingestion of zinc salts such as zinc chloride is characterized by corrosion and inflammation of the mucous membrane of the mouth and stomach, which usually becomes white; ulceration of the stomach may occur, often followed by perforation. Symptoms include burning pains in the oesophagus and stomach, nausea and vomiting, diarrhea, hypotension, cold sweats and cramps in the legs. Oesophageal or gastrointestinal stricture may follow [8].

Black Stone Hair Dye (BSHD) is popularly used as Hair dye in south of Upper Egypt and many cases of human poisoning and death has been reported as suicide and homicide, Black Stone Hair Dye (BSHD) contains Para-phenylenediamine addition more elements. Paraphenylenediamine, a derivative of paranitroaniline, PPD is commonly mixed with henna, which is traditionally applied to colour the palms of hands and to dye the hairs.

P-PhenyleneDiamine (PPD) also called 1, 4 diaminobenzene is an aromatic amine used as component of engineering polymers and composites, textile dyes and pigments. PPD is colorless slightly pink grey or yellow crystalline solid and oxidized through exposure to air, it turns white, brown and the final stage black.

\section{Materials and Methods}

Kohl was collected from Shattora Village-Sohag state and P-PhenyleneDiamine (PPD) was collected from Assuit state in Egypt and digested by Ethos PRO. Liver and kidney tissues samples were received from Medico legal Assuit chemical lab department and these samples were taken from two cases of suicidal in fourth decade.

*Corresponding author: Ahmed Shihata, Forensic Medicine Authority, Assuit University, Egypt, Tel: +201091449737; E-mail: ahmed_shihata_7@yahoo.com

Received November 09, 2017; Accepted December 20, 2017; Published January 02, 2018

Citation: Shihata A (2018) Comparison Study of Toxicity Kohl and Black Stone Hair Dye. J Environ Anal Toxicol 8: 539. doi: 10.4172/2161-0525.1000539

Copyright: $\odot 2018$ Shihata A. This is an open-access article distributed under the terms of the Creative Commons Attribution License, which permits unrestricted use, distribution, and reproduction in any medium, provided the original author and source are credited. 


\begin{tabular}{|c|c|c|c|c|c|c|c|c|c|}
\hline Parameter mg/l & Mg & $\mathrm{Ca}$ & Al & B & $\mathrm{Ba}$ & Cd & Co & $\mathrm{Cr}$ & $\mathrm{Cu}$ \\
\hline Kohl & 111.66 & 1188.6 & 145.34 & $\mathrm{Nd}$ & 40.68 & $<0.004$ & $<0.005$ & $<0.007$ & 98.86 \\
\hline Black Stone Hair Dye & 52.24 & 586.8 & 45.44 & $\mathrm{Nd}$ & 6.98 & 3.28 & 2.42 & $<0.007$ & 24.26 \\
\hline Parameter mg/l & $\mathrm{Fe}$ & Mn & Mo & $\mathrm{Ni}$ & $\mathrm{Pb}$ & Ag & Va & Zn & \\
\hline Kohl & 43.04 & 7.32 & 3.78 & $<0.007$ & 62620 & $<0.02$ & $<0.007$ & 192.82 & \\
\hline Black Stone Hair Dye & 29.76 & 5.46 & $<0.001$ & 2.76 & 45 & $<0.02$ & $<0.007$ & 32.2 & \\
\hline
\end{tabular}

Table 1: Determination of elements in Kohl and Black Stone hair Dye.

\begin{tabular}{|c|c|c|c|c|c|c|c|c|c|}
\hline Parameter mg/l & Mg & $\mathbf{C a}$ & Al & B & $\mathrm{Ba}$ & Cd & Co & $\mathrm{Cr}$ & $\mathrm{Cu}$ \\
\hline Kidney & 40.52 & 720.7 & 53.3 & $\mathrm{Nd}$ & 0.127 & 1.188 & 0.006 & 0.005 & 1.25 \\
\hline Liver & 108.7 & 750.6 & 19.63 & $\mathrm{Nd}$ & 0.3 & 0.29 & 0.0063 & 0.04 & 2.8 \\
\hline Parameter mg/l & $\mathrm{Fe}$ & Mn & Mo & $\mathbf{N i}$ & $\mathrm{Pb}$ & $\mathrm{Ag}$ & Va & $\mathrm{Zn}$ & \\
\hline Kidney & 25.33 & 0.8 & 0.9 & $<0.007$ & 6.24 & $<0.02$ & $<0.007$ & 9.4 & \\
\hline Liver & 46.47 & 1.21 & 0.14 & 0.025 & 6.35 & $<0.02$ & $<0.007$ & 20.41 & \\
\hline
\end{tabular}

Table 2: Determination of elements of Kohl in kidney and liver of woman.

\begin{tabular}{|c|c|c|c|c|c|c|c|c|c|}
\hline Parameter mg/l & Mg & $\mathrm{Ca}$ & Al & B & $\mathrm{Ba}$ & Cd & Co & $\mathrm{Cr}$ & $\mathrm{Cu}$ \\
\hline Kidney & 33.15 & 35.02 & 0.97 & ND & ND & 0.516 & 0.012 & 0.087 & 0.096 \\
\hline Liver & 21.27 & 45.25 & 0.637 & ND & 0.01 & 1.73 & 0.011 & 0.072 & 1.095 \\
\hline Parameter mg/l & $\mathrm{Fe}$ & Mn & Mo & & & $\mathrm{Pb}$ & Ag & Va & Zn \\
\hline Kidney & 11.04 & 0.5 & ND & & & 0.046 & 0.253 & $<0.007$ & 4.29 \\
\hline Liver & 7.45 & 1.1 & ND & & & 0.1 & 0.15 & $<0.007$ & 8.69 \\
\hline
\end{tabular}

Table 3: Determination of elements of Black Stone hair Dye in kidney and liver of woman.

Method of extraction was including digestion $50 \mathrm{gm}$ of liver and kidney from each case by $10 \mathrm{~N} \mathrm{HCl}$ and valued in water bath, after night residue of tissues was filtered. Black stone Hair Dye was tested by TLC on silica gel plates and chloroform: methanol $(4: 1 \mathrm{v} / \mathrm{v})$. Heavy metals of Kohl, P-PhenyleneDiamine (PPD) and residue of tissues were analyzed by Plasma Emission Mass spectrometer POEMS (thermo Jarrell Ash Co USA).

\section{Results and Discussion}

Two materials are used cosmetic (Kohl and black stone hair dye) in Egypt and some other countries. Kohl is used to make more attractive and black stone hair dye to make hair bright blacker. Unfortunately, many cases of homicide and suicide were recorded specialized by black stone hair dye in south of Upper Egypt, one case only was recorded by kohl. Seventeen elements are determined ( $\mathrm{Mg}, \mathrm{Ca}, \mathrm{Al}, \mathrm{B}, \mathrm{Ba}, \mathrm{Cd}, \mathrm{Co}, \mathrm{Cr}$, $\mathrm{Cu}, \mathrm{Fe}, \mathrm{Mn}, \mathrm{Mo}, \mathrm{Ni}, \mathrm{Pb}, \mathrm{Ag}$, $\mathrm{Va}$ and $\mathrm{Zn}$ ). Kohl is classified by toxicologists as non-volatile inorganic poison because contains high concentration of metals lead and zinc, aluminum, copper, iron, calcium, magnesium and as on Table 1.

Black stone Hair Dye is classified by toxicologists as non-volatile organic and inorganic poisons because contains P-PhenyleneDiamine (PPD) and the more concentrations in black stone hair dye are Aluminum, Lead, zinc, iron, cupper, Calcium, Magnesium and as on Table 1.

Inorganic metals toxicity such as lead and cadmium and as on if compounds or materials contain metal the toxicity effective are increased by assemblage more than metals and that raise lethal toxicity on compound or the materials. From Table 1, metal toxicity and concentrations, its show that toxicity of Kohl more than Black stone hair Dye and these elements and other determined are more than allowed according to WHO and Egyptian Health of Organization. Lead and Cadmium has no known biological role in the body. The toxicity comes from its ability to mimic, other biologically important metals, the most notable of which are calcium, iron and zinc. Lead is able to bind to and interact with protein and mole as these metals, but after displacement, those molecules function differently and fail to carry out the same reactions, such as in producing enzymes necessary for certain biological process.

Lead exposure causes damage the kidneys and gastrointestinal tract and it can lead to a host of neurological problems including impaired cognitive development in children and increased behavior problems among children and adults. The symptoms of chronic metals poisoning include neurological problems, such as nausea, abdominal pain, irritability, insomnia, excess lethargy or hyperactivity, headache and in extreme cases seizure and coma. There are also associated gastrointestinal problems, such as constipation, diarrhea, abdominal pain, vomiting, poor appetite, weight loss which are common in acute poisoning. Other associated affects kindness problems and reproductive problems, when its acute oral administration the effective is clearer.

Lead is a known carcinogen and hormone disruptor. It's readily absorbed through the skin and accumulates in the bones. It causes neurological damage and behavior abnormalities and large accumulation can result in leg cramps, muscle weakness numbness and depression. From that toxicity of poisoning metals has serious consequences which may eventually lead to death. Vomiting, gastritis, hypertension, vertigo, tremors, and convulsions have been reported [9]. We report a case of accidental ingestion of PPD, depicting all the characteristic clinical features. Vomiting, gastritis, hypertension, vertigo, tremors, and convulsions have been reported [10].

Metals are more concentrations in woman liver and kidney of Kohl than woman Black Stone Hair Dye because the higher concentration of components and higher dose (Tables 2 and 3). Lowest concentration of metals in woman of Black Stone Hair Dye spite contains more metals that is confirm other reason cause death is main component of PPD. Heavy metals accumulation in liver such as $\mathrm{Cu}$ and $\mathrm{Pb}, \mathrm{Zn}, \mathrm{Co}, \mathrm{Cr}, \mathrm{Fe}$, .... are effective in liver enzymes and other biological functions. 
From Tables 2 and 3 generally concentrations of elements in the liver higher than the kidney, and the body can't excrete it, these result guides to toxicity effect of elements in the body. Both liver and kidney in two women has higher concentration of elements and higher concentrations affected in organs of biological functions and hormones.

The toxicity of PPD includes skin irritation, contact dermatitis, chemosis, lacrimation, exophthalmos, or even permanent blindness, due to local contact. Ingestion of PPD produces two types of toxic effects. The first consists of rapid development of severe oedema of the face, neck, pharynx, tongue, and larynx with respiratory distress, often requiring tracheostomy. In the later phase, rhabdomyolysis and acute tubular necrosis supervene [11-15] and oral- rat of PPD is $\mathrm{LD}_{50} 80 \mathrm{mg} /$ $\mathrm{kg}$ and this may be due to toxicity of Black Stone Hair Dye than Kohl specialized (BSHD) contains same elements but lower concentrated.

\section{Conclusion}

In conclusion Kohl and Black Stone Hair Dye are contained more heavy metals above permissible levels and these materials available in middle east and has poison effects in children and women. Experts in branches medicine and environmental must be aware people from these cosmetic kohl and black stone hair dye and the governments must be but control in sued these compounds.

\section{References}

1. Brown VJ (2013) Metals in lip products: a cause for concern? Environ Health Prespect 121: A196.

2. US Environmental Protection Agency (EPA) (1986) Air Quality Criteria for Lead. Vol. I of IV. Environmental Criteria and Assessment Office, Research Triangle Park NC. EPA-600/8-83/028aF. Available from NTIS, Springfield, VA. PB87-142378.
3. Noji EK, Kelen GD (1989) Manual of toxicologic emergencies. Year Book Medical Publishers Inc., Chicago, USA.

4. Friberg $L(1950)$ Health hazards in the manufacture of alkaline accumulators with special reference to chronic cadmium poisoning. Acta Med Scand 138: $1-124$.

5. Gabbiani G (1966) Action of cadmium chloride on sensory ganglia. Experientia 22: 386-399.

6. Pařizek J (1957) The destructive effect of cadmium ion on testicular tissue and its prevention by zinc. Journal of Endocrinology 15: 56-63.

7. Singh RP, Kumar S, Nada R, Prasad R (2006) Evaluation of copper toxicity in isolated human peripheral blood mononuclear cells and it's attenuation by zinc: ex vivo. Molecular and Cellular Biochemistry 282: 13-21.

8. Reynolds JEF (1982) Martindale, the Extra Pharmacopoeia. 28th edn. Pharmaceutical Press, London, UK, p: 943.

9. MacPhee DG, Podger DM (1975) Hair dyes. Med J Aust 2: 33.

10. Singla S, Miglani S, Lal AK, Gupta P, Agarwal AK (2005) Para-phenylenediamine (PPD) poisoning. Journal of the Indian Academy of Clinical Medicine 6: 236238.

11. Gabow PH, Kachny WD, Kelleher SP (1982) The spectrum of rhabdomyolysis. Medicine 61: 14-52.

12. Gosselin RE, Smith RP, Hodge HC (1984) Clinical Toxicology of Commercial Products. 5th edn. Baltimore, Williams \& Wilkins.

13. Yousef MI (2004) Aluminium-induced changes in hemato-biochemical parameters, lipid peroxidation and enzyme activities of male rabbits: protective role of ascorbic acid. Toxicology 199: 47-57.

14. Sahar Y, Rania A (2016) Determination of Toxic Contents and Metals in Different Cosmetic Products in the Arabian Market. J Environ Anal Toxicol 6:3

15. Ibrahim S (2016) Determination of Heavy Metals and Other Toxic Ingredients in Henna. J Environ Anal Toxicol 6: 3. 